\title{
Tringer László professzor 80 éves
}

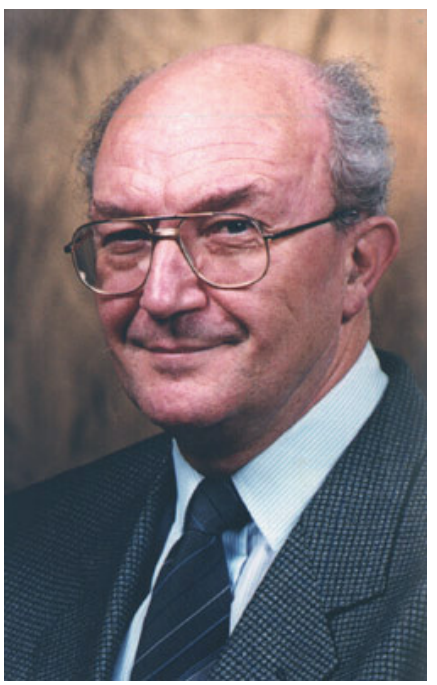

Tringer László 1939. április 2-án született Győrszentmártonban (1965 óta Pannonhalma). Saját szavai szerint az a történelem, amelyet személyesen átfog, 1862-ben kezdődik: akkor született dédnagyanyja, akivel annak haláláig (Ő akkor 10 éves volt) szoros kapcsolata volt. Bevezetésképp ezt azért érdemes megjegyezni, mert Tringer professzor szinte kortalanul úgy jelenít meg születése előtti eseményeket is, mint amelyek akár az ő életében is történhettek volna. Édesapját, aki ács volt, korán elveszítette. Szeret (és tud!) szerelni, büszkén beszél arról, hogy sokat tanult édesapjától. Pannonhalmán végezte iskoláit, ott érettségizett a Szent Benedek-rendi Katolikus Általános Gimnáziumban 1957-ben. Aki szinte semmit nem tud Tringer László életének részleteiről, az is gyakran tud Pannonhalmához füződő kötődéséről: az otthon, a Gimnázium, az ottani tanároktól kapott útravaló, a sajnos egyre fogyó öregdiákokkal, de szerencsére a későbbi évfolyamokban érettségizettekkel való találkozók és az Apátsággal való élő kapcsolata meghatározó értékek az életében. Pannonhalma város díszpolgára. 2009-ben Szent Márton-díjjal tüntették ki. Az Esztergom-Budapesti Főegyházmegye szakértőjeként a Szent Adalbert Díj birtokosa. A Metropolitan-und Diözesangericht Wien szakértője.

Tringer László klasszikus professzor. Több nyelven beszél, számos területen és szakterületen képzett. A holt nyelvek tanulmányozásán kívül beszél, oktat és elöad angolul, franciául és németül. Mint e születésnapi köszöntő szerzője írhatom, hogy „szerencsénkre” a pszichiátriát választotta, amikor 1963-ban elvégezte a Budapesti Orvostudományi Egyetemet. Érdeklődése alapján belgyógyász is lehetett volna, ha akkor „A centrencephalon pszichopatológiája" címú pályázata alapján nem hívja Nyírő Gyula professzor a budapesti Balassa utcai Klinikára (ahová már diákként bejárt). Széles körű képzettségét, tudását csak részben tükrözik tanulmányai. Szakvizsgát tett vagy azzal ekvivalens tanulmányokat folytatott a következő szakterületeken: ideggyógyászat, elmegyógyászat, pszichoterápia, addiktológia, geriátria, igazságügyi pszichiátria, rehabilitáció, orvosi pszichológia, klinikai pszichológia. Az orvosi tanulmányokon túl pszichológiát tanult az Eötvös Loránd Tudományegyetem Bölcsészettudományi Karán (1969-1974) és teológiát a Pázmány Péter Katolikus Egyetemen (1987-1990).

Annak ellenére, hogy Nyírő professzor mellett csak 3 évet dolgozhatott annak váratlan halála miatt, ő saját magát és mi is őt Nyírō-tanítványként tartjuk számon. Nyírő után Juhász Pállal töltött hosszabb időt; az ő igazgatása alatt Tringer László nemzetközi hírnévvel rendelkező klinikus, osztályvezető, neuróziskutató szakemberré vált. Úttörőként dolgozott a különböző pszichoterápiák hazai meghonosításán, múvelésén és az orvostudományba történő integrálásán. Érdemes hangsúlyozni, hogy a pszichoterápiát az orvoslás, és nem a pszichiátria részének tekinti. Kiemelendő a viselkedésterápiák területén folytatott munkássága és a viselkedésterápiák ún. „kognitív fordulatában” való tevékenysége. A „gyógyító beszélgetés", a Rogers nevéhez füződő ún. klienscentrikus pszichoterápia meghonosításában is aktív szerepet vállalt. Pszichoterapeuta generációk képzésében vett részt. 1974/75-ben egy tanévet Párizsban, Pichot professzor mellett dolgozott. Jelenleg is élő francia kapcsolatai vannak.

Tringer professzor a „szolgálatot” tanította nekünk. A pszichiátriai kutatás, oktatás és ellátás szolgáltatóipari ágazattá vagy gyári termeléshez való alakításában-alakulásában rejlő ellentmondásokat és veszélyeket évtizedekkel ezelőtt meglátta. A betegek érdekeit képviselve szembesített például engem is azzal már évtizedekkel ezelőtt, hogy múködésünk „elitista” átalakulása sértheti a betegek szolgálatát. A Juhász Klinikán, amely nagy területet látott el, nem volt egyetlen osztály sem bezárva. Ezen a Klinikán Tringer László terápiás közösségi elvek alapján múködtette az osztályt, miután a Klinika Nyéki úti épületét az Egyetemnek fel kellett adnia. A hazai pszichiátriai közösségi mozgalom még meg sem született, amikor már kimagasló sikerű korszerű ellátási formát hozott létre. A Balassa utcai Klinikát 1984-ben Dél-Pestre, a Jahn Ferenc Kórházba költöztették az épület felújítása miatt. Ekkor Tringer László vállalta, hogy a pszichoterápiás ellátást ugyanúgy teljesítjük ágyak nélkül is, mint korábban 
az ágyakkal rendelkező klinikai osztályon. A híressé vált „Nap utcai modell”-t a VIII. kerületben valósította meg: lakossághoz közeli, könnyen elérhető, magasan képzett szakemberek által nyújtott ambuláns ellátást szervezett. Szellemi múhely is lett a Nap utcai rendelő (és ma is az), a gyakori vendégek között szerepeltek a rádió, a televízió és az írott sajtó munkatársai. Mozgalmi felhangok nélkül vett részt egy önsegítő betegcsoport létrehozásában (1983), és segítette munkájukat, majd távolról követte tevékenységüket, amikor már önállóan tudott a csoport tevékenykedni.

1989-ben kapott egyetemi tanári kinevezést. 1990-től a Szenátus tagja, az Oktatási és Nevelési Bizottság tagja. 1991-ben - Réthelyi Miklós rektor megbízásából - ő képviselte egyetemünket a Kútvölgyi Kórház átvételével kapcsolatos minisztériumi tárgyalások során. Kidolgozta a kórház „Oktató Kórházzá” történő átszervezésének programját. 1991 és 1994 között a Semmelweis Egyetem Oktató Kórházává vált „Kútvölgyinek” az igazgatója, és az ottani pszichiátriai és pszichoterápiás osztály vezetője. Az osztályt fejlesztette, szakmai profillal is bövítette, azonban ezek egy jelentős része áldozatul esett az 1996-os osztálybezárási hullámnak. Ebben az időszakban, egy külföldi utazásunk alkalmával folytatott beszélgetésben mondta el nekem javaslatait arról, hogyan lehetne az orvosképzés színvonalát javítani. Ez nem sokkal azután történt, hogy hazatértem a Semmelweis Egyetemre a New York University-ról. Világos volt számomra, hogy Laci nem elitista, és nem is feltétlenül elit, de élvonalbeli egyetemet szeretne csinálni a budapesti volt orvoskarból. Az, hogy ez a törekvés hogyan bukott meg, tanulságos lehet a mai vezetőknek is.

1994-tôl 2004-ig volt a budapesti Pszichiátriai és Pszichoterápiás Klinika igazgatója. Ez az az időszak, amikor itthon a „HBCS-gyár” és az antipszichiátriai mozgalmak erősödtek. Tringer professzor sok energiát fordított arra, hogy a Klinika békés, jó hangulatát megőrizze, és arra, hogy a betegellátás és az oktatás színvonala ne csorbuljon. Miután 2014-ben átadta klinikai igazgatói feladatait, óraadó tanára lett a Sapientia Szerzetesi Hittudományi Főiskolának, és 2008-ban elvállalta a szegedi Gál Ferenc Főiskola Neveléstudományi Tanszékének vezetését.

Közben feleségével, Katival, akit gyógytornászként és tanárként sokan ismernek, felneveltek 3 gyermeket, és jöttek az unokák. Laci a sok munkaórát felölelő hetek után vagy mellett szigorúan őrizte a családnak szentelt időt (például a biciklitúrák vagy a húsvét előtti elvonulás
Pannonhalmára és az esztergomi házban tölthető idő). A ház körüli hatalmas kert karbantartását is ő végezte.

„A Hamilton-féle depressziós skála alkalmazása” címú közleménye 1970-ben jelent meg az Ideggyógyászati Szemlében, mely jól dokumentálja úttörő szerepét a pszichometria hazai meghonosításában is. 1979-ben lett az orvostudományok kandidátusa, melyben igen elegánsan, papír-ceruza tesztekkel igazolta a jelfeldolgozás zavarát neurózisokban. Pszichoterápiás tevékenységét sok közlemény és több könyv dokumentálja. Az általa írt tankönyvből generációk tanulhattak, illetve tanulhatnak pszichiátriát.

Az 1980-ban megalakult Magyar Pszichiátriai Társaság alapító tagja, később titkára, majd elnöke. Tagja és elnöke is volt a Szakmai Kollégiumnak, és vezetője volt a Nemzeti Egészségvédelmi-Egészségfejlesztési Intézet Mentálhigiénés Programirodájának. Társadalmi funkciókat is vállalt, például Budapest VIII. kerületében, lakóhelyén, a helyi önkormányzat Egészségügyi és Sportbizottságának elnöke (1989-1991) és a Magyar Orvosi Kamara Egyetemi Szervezete Etikai Bizottságának a tagja volt éveken át.

Amikor a PhD-képzés elindult a Semmelweis Egyetemen, megalapította a ma Mentális Egészségtudományok nevú doktori iskolát.

A Jeruzsálemi Szent Sír Lovagrend meghívta tagjai sorába, majd a Lovagrend magyarországi helytartója lett.

Ebben a méltató köszöntésben nem törekedtem Tringer professzor pályája minden részletének leírására. Ma is aktív, több nyelven oktat, hetente többször van benn a Klinikán. Tankönyvének új kiadását előkészítette, melyet egyedül írt, ahogy nyilatkozta, Nyírő nyomdokaiban, akinek fél évszázaddal ezelőtt egyedül írott pszichiátriatankönyve példa számára.

Ahogy fenn írtam, Tringer László nagy tudású, klaszszikus professzor, három diploma és több szakvizsga jelzi széles körü érdeklődését és képzettségét. Távol áll tőle a szúk körü, szakmai elfogultságon alapuló értékrend és az erre épülő képzés és kutatás. Több évtizedes szakmai tevékenységével, bölcsességével, kiegyensúlyozott egyéniségével erôs szellemi hidat jelent a múlt és a jövő között.

Másfél évtizede lehetett, amikor Laci azt mondta nekem: minden napra úgy tekint, mint egy ajándékra. Nagyon sok ilyen ajándékot, jó egészséget és boldogságot kívánok Neked 80. születésnapod alkalmából családom és kollégáim nevében!

Bitter István dr.

\section{"Artificem commendat opus." (Az alkotót alkotása dicséri.)}

